\title{
Biological Stability of Water after the Biofiltration Process
}

\author{
Justyna Zamorska' \\ 1 Department of Water Purification and Protection, Rzeszow University of Technology, Al. Powstańców War- \\ szawy 6, 35-959 Rzeszów, Poland, e-mail: jzamor@prz.edu.pl
}

\begin{abstract}
One of the most frequently implemented processes in the water treatment technology is filtration through a biosorption bed. The techniques based on biochemical processes involving bacteria result in obtaining high quality of water. There are a number of different materials used as the filler material for biological filters. Carbon deposits are the most popular, due to their high effectiveness. The problem with the use of this process is the leaching of microorganisms from the biofilm and the biological stability of water thus obtained. There is a need to develop quick methods to assess the microbiological quality of this water. Modern techniques for determining the amount of microorganisms, such as flow cytometry and luminometry may be the right tools. The water collected for testing came from the Water Treatment Station located in the Podkarpackie voivodeship. The microbiological tests carried out in the analyzed water samples collected after the filtration process on granular activated carbon. Both traditional culture method and modern techniques used to determine the number of microorganisms (flow cytometry, luminometric ATP assay) demonstrated an increase in the number of microorganisms in the examined waters (in the water after the filtration process and in the water introduced into the water supply network) after the incubation process for 3 and 7 days at 15 and $22^{\circ} \mathrm{C}$.
\end{abstract}

Keywords: biofiltration, microbiology of water, biological stability of water, flow cytometry

\section{INTRODUCTION}

The mechanism of water purification using a biosorption bed is a complicated process. It consists of a series of changes on a physical, chemical and biological basis. In addition, the water treatment technology based on this type of deposit involves the physicochemical (adsorption, flocculation) and biochemical (nitrification, denitrification, biodegradation) processes. They occur with the involvement of the enzymes transferred with the help of a biological membrane. The groups of organisms present in the deposit are responsible for all of the processes. They are characterized by an extraordinary sensitivity to thermal fluctuations and physicochemical parameters of water. All of the changes occur directly in their cells as well as in the pores and channels of the filling material. Their number depends on the season and time of operation of the bioreactor [Papciak, 2011].

The implementation of the biotechnological purification mechanism offers many other benefits. It allows, among other things, elimination of micropollutants of organic and inorganic origin from water. This results in the removal of the causes responsible for the variability of water's biological stability. In addition, it reduces the risk related to the multiplication of colonies of individual microorganisms in the devices used for water treatment and distribution. Introduction and application of biotechnological methods offers the opportunity to reduce the demand of the treated water for disinfectants, e.g. chlorine. This also enables to reduce the possibility of side products resulting from the disinfection process [Tchórzewska-Cieślak, 2017].

Directly during the filtration process, a large number of microorganisms is introduced into the filter surfaces, along with the treated water. Most of them remain on the surface of the material that fills the filter, and when the facilities are cleaned, they are removed outside. The remaining microorganisms infiltrate into the filter, contributing to the formation of a coating that increases 
the sorption capacity of the bed - the biological membrane. It constitutes a slimy layer that immediately adjoins the porous surface of the filter material that is the bed filling [Magrel, 2000].

The microorganisms present on the surface of the biosorption bed, like the filling material, serve a double role. They are responsible for the biochemical decomposition of chemical substances and participate in the biodegradation of the carrier itself. Therefore, the efficiency of removing pollutants is described by the resultant sorption and biodegradation [Papciak, 2011].

The biosorption process on the activated carbon is a mechanism that is commonly used in modern water treatment stations. The effectiveness of carbon filters depends on both the adsorption mechanism and biochemical processes. The biomass present on biologically active carbon filters supports the process of reducing the amount of pollutants from treated water. This involves the biochemical oxidation of readily biodegradable compounds of organic origin and biological nitrification of ammonium compounds. The intensity of the processes taking place in the filter and the interactions between adsorption and biodegradation are determined by the variability of the chemical oxygen demand, the amount of dissolved oxygen and total organic carbon as well as the metabolic efficiency of the biomass [Kijowska, 2000].

The biomass present on biologically active carbon filters supports the process of reducing the amount of pollutants from treated water. This involves the biochemical oxidation of readily biodegradable compounds of organic origin and the biological nitrification of ammonium compounds. The intensity of the processes taking place in the filter and the interactions between adsorption and biodegradation are determined by the variability of the chemical oxygen demand, the amount of dissolved oxygen and total organic carbon, as well as the metabolic efficiency of the biomass. The biological observations of groups of organisms present on granular activated carbon include several methods. There is the possibility of carrying out the research using the number of bacteria, using direct counting and culture techniques, estimating the amount and parameters of bacteria by means of molecular methods, ATP levels, nucleic acids and phospholipids, testing the rate of action of selected enzymes, residues after biochemical transformations and the content of animal organisms [Łebkowska, 2016].
Biologically stable water is the water intended for human consumption which, within the area of the water supply network and during the entire cycle of its delivery to the consumer, does not change its microbiological parameters. The studies on the biological stability conducted over the last 30 years allow us to determine the quality of water through the growth potential of microorganisms. The factors conditioning the development of microorganisms are compounds of nitrogen and phosphorus with an inorganic basis. The existence of self-supporting microorganisms, including chemoautotrophs, is determined by the presence of hydrogen, carbon dioxide or sulfur (II), manganese (II) and iron (II) compounds. The presence of biodegradable organic compounds in the dissolved state, including the biodegradable dissolved organic carbon-BDOC, is also significant. The indicators for BDOC are, for example, absorbed organic carbon (AOC), or a biodegradable fraction present in the form of dissolved organic carbon (BDOC) [Lautenschlanger, 2012]. The presence of various organic carbon forms refers to the creation of the conditions conducive to the growth and development of heterotrophic microorganisms. Often, pathogenic organisms are ascribed to the group of heterotrophic organisms. The nutrients for this group of microorganisms also include numerous iron and sulfur compounds that are in oxidized form. The parallel occurrence of organic and inorganic substrates gives rise to the growth of mixotrophic microorganisms [Wolska, 2015]

The purpose of the work was to assess the water stability after biofiltration process on the activated carbon WG-12 and the water introduced into the water supply network.

\section{RESEARCH METHODOLOGY}

The water for the research was collected from the Water Treatment Station located in the Podkarpackie voivodeship. The water was based on the surface waters. The water treatment process include: initial disinfection of water using ozone, coagulation process supported by the use of a synthetic-origin flocculant, as well as the sedimentation mechanism taking place in horizontal settling tanks; filtration process using rapid filters with sand, anthracite-sand and activated carbon filling and final disinfection. 
The analysis was carried out on the water collected on the production line (raw water):

- Water 1 - water after the biofiltration process on bed with activated carbon and,

- Water 2 - treated water (after final disinfection) introduced into the water supply network.

These waters were then incubated for three and seven days. The time of 3 and 7 days was taken as a necessary period for the re-growth of bacteria, if appropriate conditions for their development were present in the tested water. Incubation was carried out in suitably adapted incubators, at temperatures of 5,15 and $22^{\circ} \mathrm{C}$. The range of markings included the following markings of the number of microorganisms by traditional culture methods.

The number of heterotrophic bacteria in $1 \mathrm{ml}$ of water was determined by the method of deep seeding: after 24 hours of incubation at $37^{\circ} \mathrm{C}-$ mesophilic bacteria and after 72 hours of incubation at $22^{\circ} \mathrm{C}$ - psychrophilic bacteria. In order to compare the development of microorganisms in various media, nutrient reference agar, henceforth referred to as Agar A and agar R2A (called further Agar R), with extended incubation time up to 7 days were used. Three replicates were performed from each sample.

\section{Marking of the number of microorganisms by flow cytometry}

The flow cytometer CyFlow Cube 6 and fluorescent dyes: SYBR Green I as well as propidium iodide were used for the tests. The samples $(100 \mu 1)$ were stained with $20 \mu 1$ SYBR Green I, and incubated in the dark for $10 \mathrm{~min}$ at $35^{\circ} \mathrm{C}$ prior to measurement. Following incubation, $100 \mu 1$ were analyzed using flow cytometer equipped with a $50 \mathrm{~mW}$ laser emitting at the fixed wavelength of $488 \mathrm{~nm}$. The same procedure was used for propidium iodide (PI). The obtained results from the cytometer were calculated into the number of microorganisms present in $1 \mathrm{ml}$ of the water tested.

\section{Luminometric marking of ATP}

The method for determining the number of living microbial cells in water is the ATP marking technique, using bioluminescence. The determination was carried out using the LuminULTRA PhotonMaster luminometer. The amount of light was determined at $600 \mathrm{~nm}$. Up to $100 \mu \mathrm{l}$ of the water sample was added $100 \mu$ enzyme luciferin. The marking was carried out at $35^{\circ} \mathrm{C}$. Then, the sample was mixed, inserted into the luminometer and the result was read in relative light units - RLU units [Lis, 2016].

\section{RESULTS AND DISCUSSION}

While analyzing the results of tests of the total amount of microorganisms in the analyzed waters, it can be concluded that the investigated waters taken directly from the technological line contain a small number of bacteria (Fig. 1 and 2). The amounts of bacteria on the Agar R medium in raw water are higher, although these are not large differences. Considering the results of studies on mesophilic and psychrophilic bacteria in all examined waters, it can be concluded that the amount of these bacteria is definitely higher on Agar R than on the reference Agar A. Agar R, as compared to other media recommended for the heterotrophic plate count (HPC), contains reduced levels of peptone, yeast extract, and dextrose. The composition of this medium, in combination with longer incubation time, can stimulate the development of a much higher number of heterotrophic bacteria, even chlorine resistant bacteria [Siebel, 2008].

The results summarized in the Figure 1 show the number of microorganisms after the 3-day incubation process. The small numbers of mesophilic organisms in the water tested shows that incubation of water samples for 3 days is not sufficient for the intensive growth of bacteria belonging to this group. In the case of psychrophilic bacteria, a 3-day incubation at 15 and $22^{\circ} \mathrm{C}$ resulted in their intensive growth and development. Higher counts of bacteria were observed in the case of water after the filtration process. This relationship can be seen especially in the case of mesophilic bacteria.

The application of temperatures of 15 and $22^{\circ} \mathrm{C}$ for a period of 7 days resulted in the redevelopment of microorganisms. This indicates the lack of water stability after the filtration process and the treated water. There is an increase in the number of mesophilic and psychrophilic microorganisms determined on Agar A and Agar R media. The low incubation temperature $\left(5^{\circ} \mathrm{C}\right)$ has clearly inhibited the growth of microorganisms but only marked on the reference 
a)

\section{Psychrofilic bacteria}

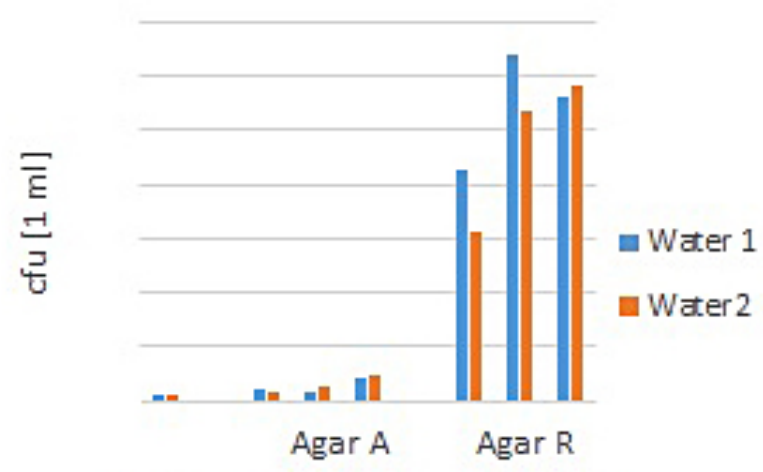

$\begin{array}{lllllll}\text { R. W. } & 5 & 15 & 22 & 5 & 15 & 22\end{array}$ b)

\section{Mesophilic bacteria}

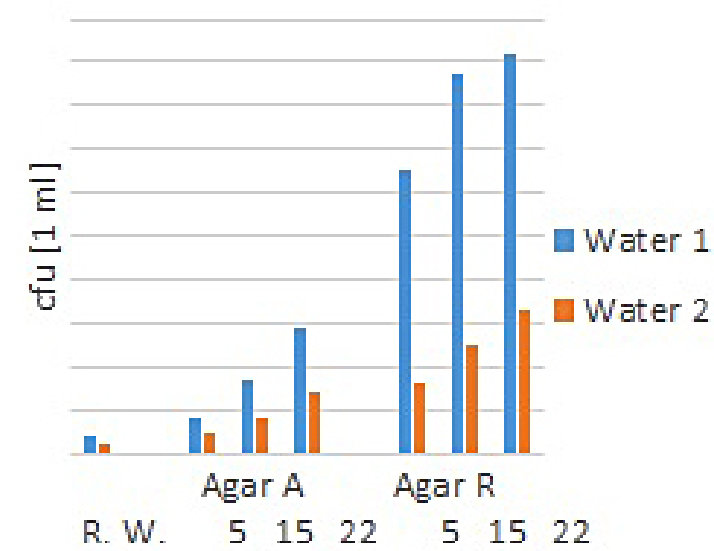

Figure 1. The numbers of heterotrophic bacteria in water after 3 days incubations: a - Psychrophilic bacteria, b-Mesophilic bacteria (R.W. - raw water)

a)

\section{Psychrofilic bacteria}

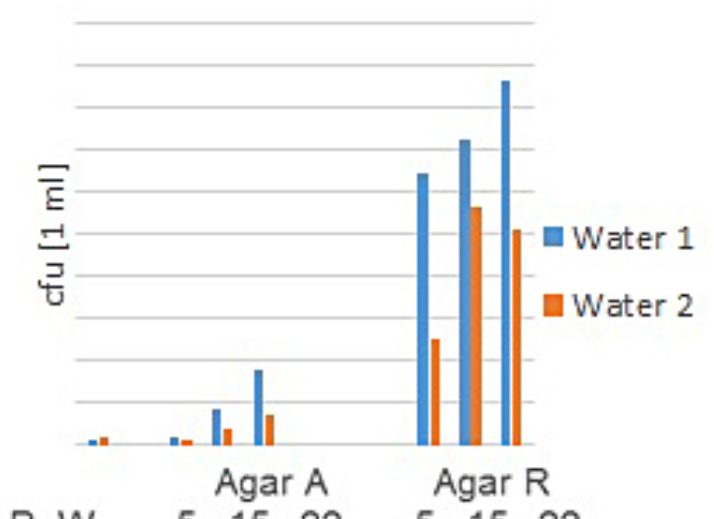

$\begin{array}{lllllll}\text { R. W. } & 5 & 15 & 22 & 5 & 15 & 22\end{array}$ b)

\section{Mesophilic bacteria}

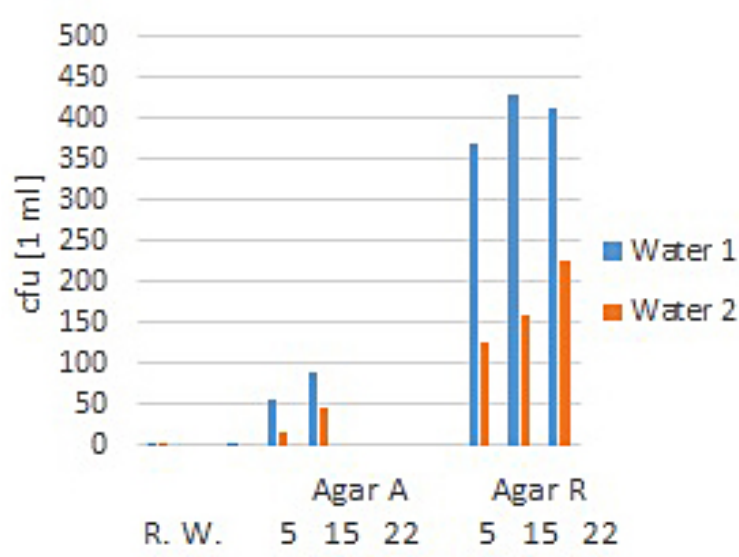

Figure 2. The numbers of heterotrophic bacteria in water after 7 days incubations: a - Psychrophilic bacteria, b - Mesophilic bacteria (R.W. - raw water)

Agar A (Fig. 2). Both in the water at the exit of the carbon filter and in the treated water after 7 days of incubation, the number of colonies of mesophilic and psychrophilic bacteria was very high. The higher bacterial counts were observed in the water after the filtration process. Such a significant increase in the number of bacteria in the tested water samples was most probably caused by the presence of biodegradable organic compounds [Świderska-Bróż, 2006].

The values pertaining to the number of microorganisms are much higher when using a flow cytometer (Fig. 3). While analyzing the obtained values, one can confirm the information provided in the literature that only an average of $1 \%$ of bacteria in water can be cultivated using traditional methods [Egli, 2008]. Such large differences in the number of microorganisms detected by the plate method and using flow cytometry are confirmed by the literature [Tingting, 2016]. In all analyzed waters, larger amounts of microorganisms were detected using SYBR Green dye. The reason for such a large number of microorganisms measured with 
a)

\section{Flow cytometry - SG}

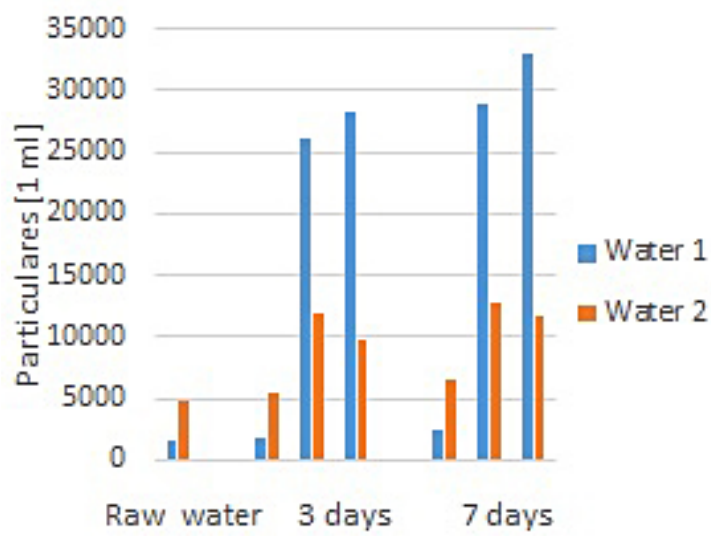

b)

\section{Flow cytometry - JP}

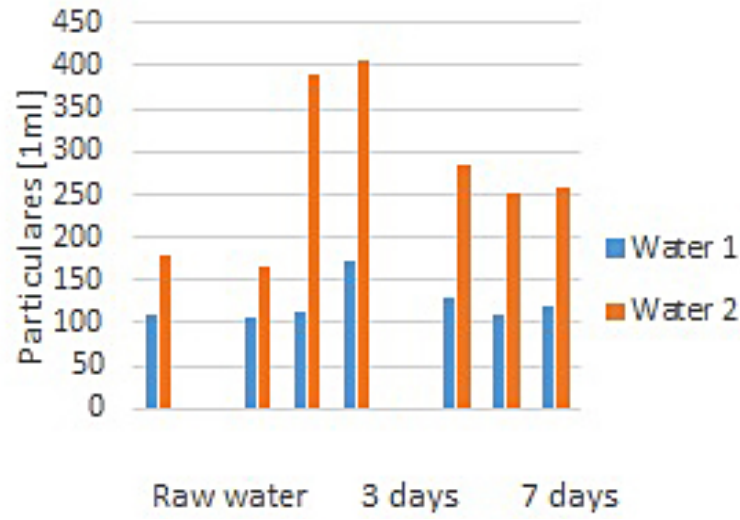

Figure 3. The numbers of microorganisms in water measured with the use flow cytometer with: a - SYBR Green, $\mathrm{b}$ - propidium iodide (R.W. - raw water)

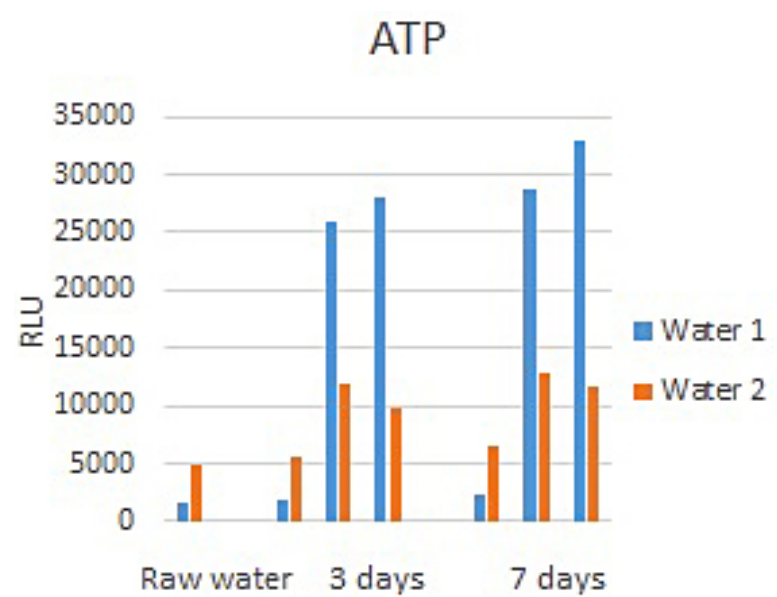

Figure 4. ATP in water after biofiltration (water 1) and treated water (water 2)

the use of a cytometer may be the fact that the SYBR Green dye used in studies involves both living and dead organisms [Hammes, 2010]. In contrast, propidium iodide theoretically does not infiltrate into the living cell. Hence, such discrepancies are found in the values of the number of microorganisms measured using these two dyes [Nevel, 2017].

The results of water quality tests performed using the luminometric method confirm the results obtained by the flow cytometry method and the traditional cultivation method (Fig. 4). RLU values are much higher in water after the filtration process. Already after three days of incubation, increase the amount of ATP at temperatures 15 and $22^{\circ} \mathrm{C}$.

\section{CONCLUSIONS}

1. The microbiological analysis of water after the biofiltration process directly on the day of water intake showed a very low number of microorganisms. Incubation of water for 3 and 7 days resulted in the intensification of the development and growth of bacteria.

2 . The results of bacteriological tests of water introduced into the water supply network indicate a lack of biological stability.

3. Biological stability tests of the waters analyzed at $15^{\circ} \mathrm{C}$ and $22^{\circ} \mathrm{C}$ showed a comparable development of bacterial microflora.

4. The reduced incubation temperature of the test water $\left(5^{\circ} \mathrm{C}\right)$ inhibited the growth of microorganisms.

5. Carrying out markings using the culture method with two differentiated agar nutrients showed significant differences in the number of cultured microorganisms. The R2A agar stimulates the development of more bacteria than agar A.

6. Determination of flow cytometry based on two different fluorescent dyes depicted the differences in the determined number of microorganisms. The applied fluorochrome pyridinium iodide (PI) had a lower content of particles in the water tested.

7. The number of microorganisms determined using the breeding method is lower in relation to the number of bacteria detected with use of modern methods (luminometric ATP marking, flow cytometry). 


\section{REFERENCES}

1. Egli T. 2008.New methods for assessing the safety of drinking water. Eewag News, 65e, 20-23.

2. Hammes F., Goldschmidt F., Vital M.2010. Measurement and interpretation of microbial adenosine tri-phosphate (ATP) in aquatic environments, Water Research, 44, 3915 -3923.

3. Kijowska E., Leszczyńska M., Sozański M.2000. The test of metabolic activity in biodegradation tests of organic matter in the biological filters of carbon filters (in Polish), IV Międzynarodowa Konferencja ,Zaopatrzenie w wodę, jakość i ochrona wód", Kraków, 477-488.

4. Lautenschlanger A., Hwang Ch. Liu W., Boon N., Koster O., Vrouwenvelder H., Egli T., Hammes F.2012. Microbiolgy - based multi - parametric approach towards assessing biological stability in drinking water distribution networks, Water Research, 47, 3015-3025.

5. Lis A., Pason Ł., Stępniak L.2016 Review of the methods used to determine the biological activity of carbon filters (in Polish), Inżynieria i Ochrona Środowiska, 19(3), 413-425.

6. Łebkowska M., Załęska-Radziwiłł M. 2016. Microorganisms positive and negative role in environmental engineering (in Polish), Oficyna Wydawnicza Politechniki Warszawskiej, Warszawa.

7. Magrel L.2000. Water and wastewater treatment, devices, processes, methods, Wydawnictwo Ekonomia i Środowisko, Białystok.
8. Nevel S., Koetzch S., Proctor C.R., Besmer M.D. 2017. Flow cytometric bacterial cell counts challenge conventional heterotrophic plate counts for routine microbiological drinking water monitoring, Water Research, 113, 191-206.

9. Papciak D., Zamorska J., Kiedryńska L.2011. Microbiology and biotechnology in water treatment processes (in Polish), Oficyna Wydawnicza Politechniki Rzeszowskiej, Rzeszów.

10. Siebel E., Wang Y., Egli T., Hammes F. 2008. Correlation between total cell concentration, total adenosine tri-phosphate concentration and heterotrophic plate counts during microbial of drinking water, Drinking Water Engineering and Science, 1, 1-6.

11. Świderska-Bróż M., Wolska M.2006, The main causes of water pollution in the distribution system (in Polish), Ochrona Środowiska, 28(4), 29-34.

12. Tchórzewska-Cieślak B., Papciak D., PietruchaUrbanik K., Pietrzyk A.2017. Method of analysis and assessment of the risk of biological instability of tap water (in Polish), Aktualne zagadnienia w uzdatnianiu i dystrybucji wody, Gliwice.

13. Tingting L., Weiwen K., Nan Ch. Jing Z., Jingqi W., Xiaoqing H., Yi J.2016, Bacterial characterization of Beijing drinking water by flow cytometry and MiSeq sequencing of the 16S rRNA gene, Ecology and Evolution, 6(4), 923- 934.

14. Wolska M., Mołczan M. 2015 Assessment of the stability of water entering the water supply network (in Polish), Ochrona Środowiska, 37(4), 51-56. 